\title{
ORTAOKUL TÜRKÇE DERS KİTAPLARINDAKİ METÍNLERİN TÜR VE TEMA AÇISINDAN İNCELENMESİ
}

Tuncay TÜRKBEN ${ }^{1}$

Atıf/C: Türkben, T., (2018). Ortaokul Türkçe ders kitaplarındaki metinlerin tür ve tema açısından incelenmesi. Hitit Üniversitesi Sosyal Bilimler Enstitüsü Dergisi, 11(3), 2152-2166. doi: 10.17218/hititsosbil.419925

Özet: Türkçe derslerinin temalar ve temalara uygun çeşitli türde metinlerle etkinlik temeline dayall, öğrenci odaklı bir anlayışla gerçekleştirilmeye çalışılması hedeflenmektedir. Bu çalışmanın amacı, ortaokul Türkçe ders kitaplarında bulunan metinleri tür ve tema açısından incelemektir. Çalışmanın başlangıç bölümünde alanyazın taraması yapılarak ders kitaplarında yer alacak metinlerin nitelikleri üzerinde durulmuştur. Çalışmalarda, metin seçiminde çocuğa görelik ilkesinden hareket edilmesi gerektiği üzerinde durulmaktadır. Ana dili öğretiminde, temel dil becerilerin geliştirilmesinde ve okuma alışkanlığının kazandırılmasında ders kitaplarına seçilecek metinlerin niteliği önem taşımaktadır. Hazırlanacak ders kitapları da bu doğrultuda özenle hazırlanmalıdır. Araştırmanın çalışma grubunu Milli Eğitim Bakanlığı Talim ve Terbiye Kurulu tarafından 2018-2019 yılında ortaokul 5, 6, 7 ve 8. sınıflar için ders kitabı olarak kabul edilen ve "MEB, Eksen ve Dersdestek" yayınevlerince hazırlanan Türkçe ders kitaplarında bulunan toplam 280 metin oluşturmaktadır. Araştırmanın çalışma grubu, yazılı belgelerle sınırlandırılmıştır. Araştırmaya dinleme / izleme ve serbest okuma metinleri de dâhil edilmiştir. Bu çalışmada, elde edilen verilerin sıklığı belirlenmiş, bulgular üzerinde tartışılmış ve konuyla ilgili önerilerde bulunulmuştur. Sonuç olarak, kitapların gerek tür gerekse tema çeşitliliği bakımından zengin olduğu görülmüştür. Aynı sınıf düzeyine yönelik hazırlanmış ders kitapları arasında metin türü ve sayılarında farklılıklar da göze çarpmaktadır.

Anahtar Kelimeler: Ortaokul, Türkçe Ders Kitabı, Metin Türü, Tema, İnceleme.

\section{Examining the Texts on Secondary School Turkish Language Course Books in Terms of Type and Theme.}

Citation/@: Türkben, T. (2018). Examining the texts on secondary school Turkish language course books in terms of type and theme. Hitit University Journal of Social Sciences Institute, 11(3), 2152-2166. doi: 10.17218/hititsosbil.419925

Abstract: It is targeted that Turkish classes are taught in a student-centered understanding based on activities with themes and various types of texts that are proper for the themes. The purpose of the present study is to examine the texts in the Turkish Course Books in Secondary Schools in terms of types and themes. In the initial step of the study, a literature review was performed and the qualities of the texts that would be included in course books were focused on. In the teaching of native language, the development of basic language skills and the acquisition of reading habits, the quality of the texts to be selected in textbooks is important. Textbooks to be prepared should be prepared carefully in this direction. The study population consisted of 280 texts that were prepared by "MEB, Eksen and Dersdestek" publishing houses. The texts were selected from the course books that were accepted by the Educational Board of Turkey of the Ministry of National Education in 2018-2019 for Secondary School $5^{\text {th }}, 6^{\text {th }}, 7^{\text {th }}$ and $8^{\text {th }}$ grades. The universe of the study was limited with written

Makale Geliş Tarihi: 30.4.2018

Makale Kabul Tarihi:6.12.2018

${ }^{1}$ Dr.Öğr.Üyesi, Aksaray Üniversitesi, Eğitim Fakültesi, Türkçe Eğitimi Anabilim Dal1, tuncayturkben57@gmail.com, http://orcid.org/ 0000-0003-0167-4173 
documents. The study included listening / viewing and free reading texts. In the present study, the frequency of the data obtained were determined, findings were discussed, and recommendations were made about the topic. As a conclusion, it was observed that the course books were extremely rich in terms of type and theme variety. The textbooks prepared for the same class level are different in the text types and numbers.

Keywords: Middle School, Turkish Course Book, Text Type, Theme, Examination.

\section{GİRIŞ}

Teknolojideki ve bilimdeki hızlı gelişme, değişmelerle birlikte eğitim alanında da değişim ve yenilenme söz konusu olmaktadır. Türkçenin eğitimi ve öğretimi alanında hedeflenen başarının gerçekleşmesi, nitelikli programlar sayesinde mümkün olacaktır. Bu da ilköğretim okullarında uygulanan Türkçe programlarının, bu değişim ve gelişmeye ayak uydurması için sürekli izlenmesi, eksiklikleri giderilerek geliştirilmesi ve yenilenmesini gerektirmektedir (Uçgun, 2014, s.103).

Eğitim kurumlarının en büyük uğraşlarından biri eğitimde kaliteyi yükseltmektir. Örgün ve yaygın eğitim kurumlarında tüm öğretim faaliyetleri önceden hazırlanan program çerçevesinde yürütüldüğünden eğitimde niteliğin geliştirilmesi önem arz etmektedir. Uygulanan programların aksaklık ve eksiklikleri giderildikçe, toplumdaki bilim alanındaki değişmelere göre yeniden düzenlendikçe, diğer bir deyişle programlar geliştirildikçe eğitimin niteliğinin de artması beklenir (Erden, 1995, s.2; Göçer, 2017, s.1).

Hiçbir öğretim programı son program olarak tasarlanmaz ve düşünülmez. Bilgi ve teknolojilerdeki hızlı değişmeler öğretim programlarına da yansımaktadır (Özcan, 2017, s.559).Türkçe Dersi Öğretim Programı da bu değişim ve gelişmelere bağlı olarak zaman içerisinde yenilenmekte ve güncellenmektedir. Yenilenen Türkçe Dersi Öğretim Programı'nda da, öğrencilerin hayat boyu kullanabilecekleri dinleme/izleme, konuşma, okuma ve yazma ile ilgili dil becerilerini ve zihinsel becerileri kazanmaları, bu becerileri kullanarak kendilerini bireysel ve sosyal yönden geliştirmeleri, etkili iletişim kurmaları, Türkçe sevgisiyle, istek duyarak okuma ve yazma alışkanlığı edinmelerini sağlayacak şekilde bilgi, beceri ve değerleri içeren bir bütünlük içinde yapılandırılmıştır. Türkçe Dersi Öğretim Programı; dil becerilerinin ve yeterliliklerinin geliştirilmesini, diğer tüm alanlarda öğrenme, kişisel ve sosyal gelişme ile mesleki becerileri edinmenin ön şartı olarak kabul etmektedir (MEB, 2018).

Tematik yaklaşım esas alınarak hazırlanan öğretim programında okuma ve yazma kazanımları metin içi, metin dışı ve metinler arası okuma yoluyla anlam oluşturmayı sağlayacak şekilde yapılandırılmıştır. Birinci sınıftan sekizinci sınıfa kadar kazanımların yapısı ve hiyerarşisi, öğrencilerin temel dil becerilerinin yanı sıra üst düzey bilişsel becerilerini geliştirmelerine katkı sağlayacak şekilde düzenlenmiştir. Öğrencilerin gelişim özellikleri göz önünde bulundurularak dil bilgisi ve yazım kuralları ile ilgili kazanımlar artan bir yoğunluk içinde ve aşamalı olarak yapilandırılmıştır (MEB, 2018).

Türkçe derslerinin temalar ve temalara uygun çeşitli türde metinlerle etkinlik temeline dayal,, öğrenci odaklı bir anlayışla gerçekleştirilmeye çalışılması öngörülmektedir (İşeri, 2014, s.91). Türkçe Dersi Öğretim Programı'nın uygulanması sürecinde her sınıf düzeyinde 8 tema işlenmesi öngörülmüştür. Bu temalardan; "Erdemler", "Millî Kültürümüz", "Millî Mücadele ve Atatürk" temalarının her sınıf düzeyinde işlenmesi zorunludur. Zorunlu temalar dışında verilen diğer temalar seçmeli olup kitap yazarlarınca belirlenebileceği ifade edilmektedir (MEB, 2018). 
Türkçe derslerinde temel dil becerilerinin kazandırılmasında metinlerden yararlanılır. Metinlerin seçiminde tüm sınıf düzeylerinde her temada 4 metin kullanılacağı ifade edilmektedir. Bu metinlerin 3'ü okuma 1'i dinleme/ izleme metnidir. Böylece kitap bütününde toplamda 32 okuma ve dinleme/izleme metni kullanılacaktır (MEB, 2018). Ders kitaplarında yer alacak metinlerin özenle seçilmesi gerektiğini ifade eden Sever'e (2013a, ss.18-19) göre, çocukta ana dili sevgisi ve okuma alışkanlığını kazandırmanın yolu, çocuğun dil ve anlam evrenine uygun nitelikli metinlerle karşılaşmasına bağlıdır.

Metin, çok farklı düzeylerde, dille iletişimde bulunmak amacıyla oluşturulan anlatma ve anlaşma aracıdır (Aktaş, 2015, s.15). Hartman ve Allison (1996, s.111) metni, 'bir fikrin veya tecrübenin yazılı olarak ifade edilmesi' şeklinde tanımlamıştır. Günay’a (2013, s.45) göre metin, "başı ve sonu ile kapalı bir yap1 oluşturan dilsel göstergelerin art arda geldiği anlamlı yapı" olarak tanımlanabilir. Günay’a göre metin, belirli bir bildirişim bağlamında bir ya da birden çok kişi tarafından sözlü ya da yazılı olarak üretilen bir dil dizgesi bütünüdür. Y1lmaz’a (2010, s.2) göre ise metin, "cümlelerin/ sözcelerin basit, rastgele, ardışık olarak sıralanması ile oluş(turul)muş basit bir yap1 değildir. Metin; en gelişmiş bildirişim dizgesi olan insan dilinin, en üst düzeydeki birimi; cümleler/ sözceler arası çeşitli düzeylerde yazar(lar)1 tarafından bilinçli olarak derin ve yatay, uzak ve yakın ilişkilerle oluşturulmuş bağdaşık, tutarlı bir dilsel düzenleme; bütünlük ve birlik arz eden, anlaşılabilen, özetlenebilen, yorumlanabilen ve metinsel, sosyal, kültürel, durumsal bağlamlar içerisinde belli çıkarımlar, sezdirimler ve iletiler içeren dilsel bir bütünlük; metinsellik özelliği taşıyan sözlü / yazılı iletişim ürünüdür." Metin "kendisini oluşturan tümce dizilerinin birbirlerine bağdaşıklık ve tutarlılık ölçütleriyle bağlanarak bir anlam bütünlüğü oluşturmasıyla meydana gelen, belli bir amaçla üretilmiş, başı ve sonu kesin çizgilerle sinırlandırılan yazılı ya da sözlü bir dilsel ürün" dür (Onursal, 2003, s.124).

Sever (2013b, s. 12), Türkçe dersleriyle varılmak istenilen genel amaçlara, öğrencilere okuma zevk ve alışkanlığı kazandırılarak ulaşabileceğini belirtmektedir. Türkçe öğretiminde, ilköğretim birinci sınıftan başlayarak öğrenciler, Türkçenin anlatım gücünü yansıtan, onların dil gelişimlerine ve gereksinimlerine uygun en özgün ürünlerle karşılaştırılmalıdır. Sanatçı duyarlılığı ile hazırlanmış yazınsal nitelikli metinler (masal, şiir, öykü, roman vb.) ile öğrenciler arasındaki iletişim süreci, onların sanatçı duyarlılığını kavramaları, sezme, kavrama, anlama becerilerini güçlendirmeleri, duygu düşünce evrenlerini genişletmeleri için olanak yaratır (Sever, 2013b, s. 20). Programa ve araştırmacılara göre ders kitaplarına seçilecek metinlerin türünün en güzel örneğinden seçilmiş olması, çocuğun dil ve anlam evrenine uygun olması, birtakım millî, ahlakî, kültürel vb. değerleri taşıması, estetik niteliği ve bütünlüğü olması ve çocukların okuma anlama, düşünme, karş1laştırma, eleştirme yeteneğini geliştirmesi, okuma kültürünü kazandıracak ve dil becerilerini geliştirecek özellikleri taşıması gerekir (Dilidüzgün, 2018, MEB, 2018; Okur, 2014, s.119; Sever, 2013c).

Dil öğretiminde şüphesiz öğrenciye sunulan metinlerin önemi büyüktür. Dili sevmek için onu öğrenme gereksinimleri ve dili öğrenirken kişiye sunulan hizmet çok önemlidir. Öğrenciye bunun bir mecburiyet olmadiğ1, Türkçe derslerine gösterecekleri ilginin ve o dersten elde edecekleri başarının onlara nasıl bir gelecek hazırlayacağı her fırsatta söylenmelidir. Öğrenciler, bu yolla motive edilerek ilgileri açık tutulmalıdır. Bu ilgiyi artırmak için Türkçenin en güzel metin örnekleri ile onlara hitap edilmelidir (Baki ve Karakuş, 2012, s.6). Bu metinlerde çocuğun kendisini ve yaşadığı dünyayı bulması gerekmektedir. Çocukların ihtiyaçlarına yönelik bilgi ve deneyimlerin sanatçı duyarlılığına sahip yazarlar tarafından özenle değerlendirilerek düzenlenmesi önem taşımaktadır (Arıc1, 2016, s.49). 
Öğrencilerin metinleri anlayabilmeleri ve metin üretebilmeleri, kısaca doğru iletişimde bulunabilmeleri için gerekli donanımları edinmeleri iyi metin örnekleriyle karşılaştırılmalarına bağlıdır. Ders kitaplarında yer alan metinlerin, Beaugrande ve Dressler (1981, ss. 1-12) tarafından tanımlanmış metin oluşturma ölçütleri olan bağlaşıklık, bağdaşıklık, amaca uygunluk, geçerlilik, bilgilendiricilik, durumsallık ve metinlerarasılık özelliklerini taşımaları gerekir.

Türkçe Öğretim Programı'nda metin türleri üç ana biçim altında toplanmıştır: Bilgilendirici, hikâye edici, şiir. Belirtilen metin sayıları içinde kalmak kaydıyla hangi temada, hangi metin türlerinin yer alacağı ders kitabı yazarının/yazarlarının tercihine bırakılmıştır (MEB, 2018).

Metinler aktarma ve düzenleme biçimlerine göre çeşitli türlere ayrılırlar. Konuyla ilgili alanyazın incelendiğinde metin türleri ile ilgili çok sayıda sınıflandırmanın yapıldığı görülmektedir. Akyol (2006) metinleri kurgu ve kurgu olmayan metinler olarak sinıflandırırken, Aktaş ve Gündüz (2014) öğretici ve edebî metinler olarak sınıflandırmaktadır. Güneş (2013, s.3; 2014), aktarma ve düzenleme biçimlerine göre metinlerin değişik şekillerde sınıflandırılabileceğini söylemektedir. Konuşma veya sözle aktarılanlara sözlü metin, yazılarla aktarılanlara yazılı metin, resim, şekil, grafik vb. görsel sembollerden oluşanlara da görsel metin; düzenleme biçimlerine göre roman, hikaye, makale, fıkra, anı, şiir vb.; basit ya da düz mantıkla yazılmış metinlere basit metinler, sarmal mantıkla yazılmış metinler ise ağır ya da üst düzey metinler; işlevleri bakımından edebî (sanat) ve öğretici metinler; dil öğretiminde kullanımına göre edebî, üretilmiş, özgün ya da otantik olarak sınıflandırılabilir. Günay (2013, s.220) ise metin türleri konusunda kesin bir sinıflama yapmanın mümkün olmadığını belirterek şu metin türleri üzerinde durmuştur: Anlatı türü, şiirsel metinler, söyleşimsel metinler, basın metinleri, özel bilgilendirici metinler, işlevsel metinler, öğretici metinler, çözümleme ile ilgili metinler, meslekî metinler, haberleşme metinleri, haberleşme metinleri, uyarıcı yazılar, panolar, pankartlar, afişler, el ilanları. Aytaş (2006) da edebî türlerin (metinlerin) tasnifini şu şekilde yapmıştır: Şiir türleri (lirik şiir, pastoral şiir, didaktik şiir, epik şiir, dramatik şiir), tiyatro, anlatı türleri (masal, destan, halk hikâyeleri, tiyatro, roman, hikâye), düşünce türleri (makale, deneme, söyleşi, eleştiri). Cemiloğlu (2015, ss. 27-64) da metin türlerini işledikleri konunun türüne göre üçe ayrılabileceğini söylemektedir:

* Olaya dayalı türler

* Düşünceye dayalı türler

* Duyguya dayalı türler olarak sinıflandırır.

Tansel (1987, s.109) ve Kantemir (1995) yazarın amacı ölçüt alındı̆̆ında metinlerin dörde ayrilabileceğini söylemektedir:

* Hikâye edici anlatım: Yazarın amacı okuru heyecanlandırmak ise olayı, okuru adeta anlatılan vakanın içine çekecek şekilde hikâye eder.

* Betimleyici anlatım: Yazarın amacı olay ve olguyu okurun zihninde canlandırmak ise yazar, o olay1 veya olguyu tasvir eder.

* Açıklayıcı anlatım: Yazarın amacı okuru bir şey hakkında bilgilendirmek ise yazar, o şey hakkında doğrudan doğruya bilgi verir.

* Íspat edici (tartışmacı) anlatım: Yazarın amacı, okuru verilen bilgiye inandırmak ise yazar, amacı doğrultusunda söylemi ispat ve delillere dayandırır. 
Tansel (1987) ve Kantemir'in (1995) sinıflandırmasına benzer bir sinıflandırmayı yapan Kiran ve Kıran (2011) da metinleri kullanılan söyleme göre "betimsel metin, anlatısal metin, açıklayıc1 metin, kanıtlayıcı metin" şeklinde dört grupta sınıflandırmıştır.

Türkçe Dersi Öğretim Programı'nda (2018, s.18) metinlerin içeriği, dil ve anlatımı ve sahip olması gereken özellikler şöyle sıralanmıştır:

1. Ders kitaplarına alanda yaygın olarak kabul görmüş yazar ve eserlerden, edebî ve kültürel değer taşıyan metinler alınmalıdır. Türk cumhuriyetleri ve Balkan Türkleri edebiyatlarından eserlere yer verilmelidir.

2. Seçilen metinler ikincil aktarımlar yerine yazarın eserinden alınmalıdır.

3. Ders kitaplarında "Bu kitap için yazılmıştır." ifadesini içeren metinler kullanılmamalıdır. Yalnızca 1.sınıf ders kitaplarında ders kitabının yazarı/yazarları tarafından yazılan en fazla iki metne yer verilebilir.

4. Aynı yayınevine ait kitaplarda bir sınıf düzeyi için seçilen metin, başka bir sınıf düzeyinde kullanılmamalıdır.

5. Öğrencilerin duygu ve düşünce dünyasını zenginleştirmek amacıyla aynı yazar ve/veya şairlerden (serbest okuma metinleri hariç, ders kitabı yazarı/yazarları tarafından yazılan metinler dâhil) en fazla iki metin seçilmelidir.

6. Dünya edebiyatından seçilen metinler, doğru ve nitelikli çevirilerden alınmalıdır.

7. Ders kitabında temaları destekler nitelikte edebî ve estetik değer taşıyan serbest okuma metinlerine yer verilmelidir.

8. Tamamı ders kitabına alınamayacak uzunluktaki roman, hikâye, tiyatro, destan gibi türlerdeki eserlerden yapılan alıntılarda eserdeki bağlamın yakalanabilmesi için metnin başında eserin seçilen bölümüne kadar olan kısmın kısa özeti verilmelidir. Seçilen metnin eserin hangi bölümünden alındığına dair kısa bir açıklama yapılmalıdır.

9. Metinlerdeki eğitsel yönden uygun olmayan ifadeler (argo ve küfür, olumsuz örnek oluşturabilecek davranışlar, cinsellik, şiddet vb. içeren unsurlar) metnin bütünlüğünü bozmamak kaydıyla çıkarılmalıdır.

10.Yazarın söyleyişinden ya da Türkçenin dönemsel söyleniş özelliklerinden kaynaklı yazım farklılıkları hata olarak nitelendirilip düzeltilmez. Metin içerisinde yer alan dönemsel farklılıklara (yazım ve noktalama) yönelik açıklamalar dipnot şeklinde verilmelidir. Ayrıca bu hususlardan öğretim amaçlı olarak yararlanılabilir.

11.Ders kitabında gazete haberi, reklam, dilekçe, tutanak, öz geçmiş, ağ günlüğü (blog), sosyal medya uygulamalarında yer alan yazı türlerinde ders kitabının yazarı/yazarları tarafından üretilen metinler de kullanılabilir. Bu türler 3 ve 5 . maddelerdeki açıklamalar kapsamında değerlendirilmez.

12.Metinlerde tema ve kazanımlara uygun olarak metnin bütünlüğü ve tutarlılığı korunmak kaydıyla bazı bölümler çıkarılarak kısaltmaya gidilebilir. Çıkarılan bölümler parantez içinde üç nokta ile gösterilmelidir.

13. Çeşitli metinler içinde yer alan kimi bağımsız ve kendi iç bütünlüğüne sahip anı, fikra, anekdot vb. bölümler metin olarak seçilebilir.

14.Yazar ve şairlerin biyografilerinde yalnızca edebî yönleri ön plana çıkarılmalıdır. 
Bu çalışmada Türkçe Öğretimi Programı'nda (2018) belirtilen metin türü ve temaların ders kitaplarında nasıl ve ne kadar yer verildiği tespit edilmeye çalışılmıştır. Ayrıca farklı yayınevleri tarafından hazırlanan ders kitapları arasında metin türü ve temaları açısından bir farklılı̆̆ın olup olmadığı da incelenmeye çalışılmıştır. Elde edilecek veriler, ders kitaplarının hazırlanmasına katkı sağlayacağ1 için önemli görülmektedir.

\section{YÖNTEM}

\subsection{Araştırmanın Konusu ve Amacı}

Bu araştırmanın amacı, ortaokul 5., 6., 7. ve 8. sınıf Türkçe ders kitaplarında hangi temalara ve metin türlerine yer verildiğini tespit etmek ve bunların sıklıklarını belirlemektir. Bu amacı gerçekleştirmek için aşağıdaki sorulara cevap aranacaktır:

1. Türkçe ders kitaplarında yer alan metinlerin türleri ve bu türlerin kitaplara göre kullanım sıklığı nedir?

2. Her kitapta toplam kaç metin türüne yer verilmiştir?

3. Kitaplarda hangi temalara yer verilmiştir? Ders kitapları arasında temalar açısından bir farklılık var midır?

\subsection{Araştırmanın Çalışma Grubu}

Bu betimsel çalışma, ortaokul 5., 6., 7. ve 8. sınıf Türkçe ders kitaplarında bulunan metinleri tür ve tema yönüyle incelemeyi amaçlamaktadır. Araştırmanın çalışma grubunu, Milli Eğitim Bakanlığı Talim ve Terbiye Kurulu tarafından 2018-2019 yılında ortaokul 5., 6., 7. ve 8. sınıfları için ders kitabı olarak kabul edilen ve "MEB, EKSEN ve DERSDESTEK" yayınevlerince hazırlanan Türkçe ders kitaplarında bulunan toplam 280 metin oluşturmaktadır. Araştırma, yazılı belgelerle sınırlandırılmıştır.

\subsection{Veri Toplama}

Araştırmada veri toplama aracı olarak doküman imcelemesi yöntemi kullanılmıştır. Doküman incelemesi, araştırılması hedeflenen olgu veya olgular hakkında bilgi içeren yazılı materyallerin analizini kapsar (Yıldırım ve Şimşek, 2013, s.217). Araştırmada veri toplama aracı olarak "MEB, EKSEN ve DERSDESTEK” yayınevlerince hazırlanan Türkçe ders kitapları kullanılmıştır. Bu kitaplar kaynakça bölümünde yıldız işareti ile belirtilmiştir.

\subsection{Veri Analizi}

$\mathrm{Bu}$ betimsel çalışmada toplanan veriler, çalışmanın amacı doğrultusunda frekans hesaplamaları kullanılarak sınıflandırılmıştır. Bu sınıflandırmada metin türlerinin ve temalarının kitaplardaki dağılımı esas alınmıştır. Kitaplardan elde edilen bulgular tablolarda sunulmuş ve bulgular yorumlanmiştır.

\section{BULGULAR ve YORUM}

Çalışmanın ilk bölümünde Türkçe ders kitaplarında yer alan okuma ve dinleme metinlerinin türleri ve sıklıkları araştırılmıştır. Elde edilen sayısal bilgiler tablolar hâlinde sunulmuş ve tartış1lmıştır. İkinci bölümünde ise ders kitaplarında yer alan temalar incelenmiştir. 


\subsection{Türkçe Ders Kitaplarındaki Metin Türlerinin Kullanım Sıklıkları}

Tablo 1. MEB Yayınevi Tarafından Hazırlanan 5. Sinıf Türkçe Ders Kitabındaki Metin Türlerinin Kullanım Siklıkları

\begin{tabular}{ll}
\hline Metin Türleri & MEB (f) \\
\hline Şiir & 10 \\
\hline Hikâye & 9 \\
\hline Masal & 2 \\
\hline Broşür & 1 \\
\hline Roman & 1 \\
\hline Fabl & 1 \\
\hline Tiyatro & 1 \\
\hline Kilavuzlar & 2 \\
\hline Haber Metni & 1 \\
\hline Film / Çizgi Film / Video & 3 \\
\hline Karikatür & 1 \\
\hline Deneme & 5 \\
\hline Makale & 2 \\
\hline Söyleşi & 1 \\
\hline Toplam & 40 \\
\hline
\end{tabular}

2018 yılında güncellenen Türkçe Dersi Öğretimi Programı'nda tüm sınıf düzeylerinde 8 tema ve her temada 4 metin kullanılacaktır. Bu metinlerin 3'ü okuma 1'i dinleme / izleme metnidir. Böylece kitap bütününde toplamda 32 okuma ve dinleme/izleme metni kullanılacaktır. Her sınıf düzeyinde temalara uygun ve eşit dağılım olması kaydıyla 8 serbest okuma metnine yer de verilmektedir. $\mathrm{Bu}$ metinlerle beraber ders kitabında toplamda 40 metin yer almaktadır. 2006 Türkçe Dersi Öğretimi Programı'nda ders kitaplarında yer alması gereken zorunlu bazı türler bulunmaktaydi. Daha sonra yenilenen ve güncelleştirilen 2015, 2017 ve 2018 programlarında böyle bir zorunluluk bulunmamaktadır. Tablo 1'de görüldüğü gibi 5. sınıf Türkçe ders kitabında on dört farklı metin türüne yer verilmiştir. Bu türlerden ikisi şiir, biri film, biri haber metni, biri çizgi film, ikisi video ve bir tanesi de masal olmak üzere 8 dinleme metni yer almaktadır. Serbest okuma metinleri arasında da 2 hikâye, 1 masal, 1 roman, 1 deneme, 2 şiir ve 1 makale yer almaktadır. 2018 Türkçe Dersi Öğretim Programı'nda sınıf düzeylerine göre yapılan metin dağılımında yer verilen dilekçe, e posta, özlü sözler, sosyal medya mesajları, çizgi roman mizahi fikra, ninni ve tekerleme gibi bazı türlere ders kitaplarında yer verilmediği görülmüştür. Bu türlerden bazılarına metin etkinliklerinde yer verildiği tespit edilmiştir.

Tablo 2. MEB ve Eksen Yayınevlerince Hazırlanan 6. Sınıf Türkçe Ders Kitaplarındaki Metin Türlerinin Kullanım Sıklıkları

\begin{tabular}{lcc}
\hline Metin Türleri & EKSEN & MEB \\
\hline Şiir & 11 & 5 \\
\hline Masal & 1 & 2 \\
\hline Makale & 9 & 4 \\
\hline Roman & 1 & - \\
\hline Deneme & 1 & 5 \\
\hline An1 & 1 & 3 \\
\hline Hikâye & 6 & 6 \\
\hline Mektup & 1 & - \\
\hline Sohbet & 2 & 2 \\
\hline
\end{tabular}




\begin{tabular}{lll}
\hline Broşür & - & 1 \\
\hline Blog & - & 1 \\
\hline Biyografi & - & 1 \\
\hline Otobiyografi & - & 1 \\
\hline Kilavuzlar & - & 1 \\
\hline Gezi Yazısı & 1 & 1 \\
\hline Fab1 & 2 & 1 \\
\hline Film / Çizgi Film & - & 2 \\
\hline Haber Metni & - & 1 \\
\hline Tiyatro & 2 & - \\
\hline Çizgi Roman & 1 & - \\
\hline Mizahi Fikra & 1 & $\mathbf{4 0}$ \\
\hline Toplam & $\mathbf{4 0}$ & \\
\hline
\end{tabular}

Tablo 2'de görüldüğü gibi bazı metin türlerine (şiir, masal, makale, deneme, anı, öykü, sohbet, fabl, gezi yazısı, tiyatro) her iki yayınevi yer verirken, bazı türlerde ise farklılıklar bulunmaktadır. Eksen Yayınevi tarafından basılan kitapta 14 farklı metin türü yer alırken, MEB tarafından basılan kitapta 17 farklı metin türü yer almaktadır. Eksen Yayınevi ders kitabıyla ders işleyen ögrenciler roman, mektup, çizgi roman, mizahi fikra gibi türlerle karş1laşacaklar. Bu türlere MEB ders kitabında yer verilmemiştir. Yine MEB ders kitabında broşür, blog, biyografi, otobiyografi, kılavuzlar, film / çizgi film, haber metni gibi türlere yer verilirken, Eksen ders kitabında bu türler yer almamaktadır. Ders kitapları arasında metin türleri açısından farklılıklar bulunduğu, farklı ders kitaplarıyla eğitim gören öğrencilerin farklı metin türleriyle karşılaşacakları anlamına gelmektedir. Eksen Yayınevi ders kitabında dinleme / izleme metinleri arasında 3 şiir, 1 anı, 1 hikâye, 2 makale, 1 roman türü yer alırken; MEB tarafından basılan kitapta 1 hikâye, 1 film/çizgi film, 1 deneme, 1 fabl, 1 biyografi, 1 türkü hikâyesi, 1 haber metni ve 1 masal türü yer almaktadır. MEB Yayınevi tarafından hazırlanan ders kitabındaki dinleme/ izleme metinleri, tür çeşitliliği yönüyle daha fazladır. Eksen Yayınevi ders kitabında serbest okuma metinleri arasında 1 deneme, 1 hikâye, 3 şiir ve 3 makale türüne yer verilirken; MEB Yayınevi ders kitabında da 1 anı, 1 blog (türkü hikâyesi yer almakta), 1 makale, 1 masal, 1 söyleşi, 1 şiir, 1 kılavuz ve 1 deneme türüne yer verilmiştir.

Tablo 3. MEB ve DERSDESTEK Yayınevi Tarafından Hazırlanan 7. Sinıf Türkçe Ders Kitaplarındaki Metin Türlerinin Kullanım Sıklıkları

\begin{tabular}{lccc}
\hline Metin Türleri & MEB- A(f) & DERSDERSTEK(f) & MEB- B(f) \\
\hline Şiir & 4 & 9 & 5 \\
\hline Biyografi & 2 & 2 & 1 \\
\hline Otobiyografi & - & - & 1 \\
\hline Hikâye & 11 & 9 & 7 \\
\hline Makale & 2 & 3 & 2 \\
\hline An1 & 4 & 2 & 2 \\
\hline Tiyatro & 1 & 1 & 2 \\
\hline Deneme & 4 & 3 & 5 \\
\hline Sohbet & 3 & 2 & 2 \\
\hline Günlük & 1 & - & 1 \\
\hline Mektup & 1 & - & 1 \\
\hline Masal & 1 & 2 & 2 \\
\hline
\end{tabular}




\begin{tabular}{lccc}
\hline Broşür & - & 1 & - \\
\hline Film/Belgesel /Video & 2 & 2 & 3 \\
\hline Çizgi Roman & 1 & - & 1 \\
\hline Roman & - & 1 & 1 \\
\hline Haber Metni & - & 1 & - \\
\hline Fabl & 1 & - & 1 \\
\hline Mizahi fikra & - & - & 1 \\
\hline Efsane & 1 & - & - \\
\hline Gezi Yazis1 & 1 & 1 & 2 \\
\hline Toplam & $\mathbf{4 0}$ & $\mathbf{4 0}$ & $\mathbf{4 0}$ \\
\hline
\end{tabular}

Tablo 3’te görüldüğü üzere 2018- 2019 eğitim öğretim yılında 7. sınıflarda 3 farklı ders kitab1 kullanılmaktadır. MEB-A'da 16, DERSDESTEK'te 14 ve MEB-B'de 18 farklı metin türü yer almaktadır. Şiir, biyografi, hikâye, makale, anı, tiyatro, deneme, sohbet, masal, film/ belgesel/ video, gezi yazısı türlerine sıklıkları farklı olmakla birlikte her üç kitap da yer vermektedir. Diğer metin türlerinde ise ders kitapları arasında farklılıklar bulunmaktadır. Bazı türlere sadece bir ders kitabı yer vermektedir. Otobiyografi (MEB- B), mizahi fikra (MEB- B), broşür (DERSDESTEK) sadece bir ders kitabında yer almaktadır. Haber metnine ise sadece Dersdestek Yayınevi yer vermiştir. Günlük, mektup, çizgi roman ve fabl türlerine ise MEB- A ve MEB- B'de yer verilirken, Dersdestek Yayınevi'nce yer verilmemiştir. MEB- A ders kitabında dinleme metinleri arasında 4 hikâye, 1 anı, 1 günlük, 1 masal, 2 film/video/ belgesel; MEB- B ders kitabında 1 şiir, 3 film /video/ belgesel, 3 hikâye, 1 gezi yazısı; Dersdestek Yayınevi'nce hazırlanan ders kitabında ise 1 biyografi, 2 film/video/belgesel, 1 tiyatro, 2 şiir ve 2 hikâye türü yer almaktadır. Serbest okuma metinlerine MEB- A ders kitabında 1 şiir, 1 tiyatro, 4 hikâye, 1 çizgi roman ve 1 gezi yazısı; MEBB ders kitabında 1 fabl, 1 mektup, 1 masal, 3 hikâye, 1 söyleşi ve 1 gezi yazısı; Dersdestek Yayınevi tarafından hazırlanan ders kitabında ise 1 anı, 1 roman, 1 deneme, 1 anı, 2 şiir, 1 makale ve 1 hikâye türüne yer verilmektedir.

Tablo 4. MEB Yayınevince Hazırlanan 8. Sınıf Türkçe Ders Kitaplarındaki Metin Türlerinin Kullanım Siklıkları

\begin{tabular}{ll}
\hline Metin Türleri & MEB \\
\hline Şiir & 8 \\
\hline Sohbet & 2 \\
\hline Biyografi & 1 \\
\hline Fabl & 1 \\
\hline Makale & 2 \\
\hline Video /Belgesel & 2 \\
\hline Mektup & 1 \\
\hline Blog & 1 \\
\hline Destan & 1 \\
\hline Efsane & 1 \\
\hline Deneme & 7 \\
\hline Tiyatro & 1 \\
\hline Masal & 3 \\
\hline Hikâye & 9 \\
\hline Toplam & $\mathbf{4 0}$ \\
\hline
\end{tabular}


8. sınıf MEB Türkçe ders kitabında kullanım sıklığı bakımından en fazla hikâye (f: 9) ve deneme (f: 7) türü yer almaktadır. Toplamda ise 14 farklı metin türüne yer verilmiştir. Fabl, mektup, destan, efsane, tiyatro türlerinde ise sadece 1 metin türü yer almaktadır. Dinleme / izleme metinleri arasında 1 söyleşi, 1 video/ belgesel, 4 hikâye, 1 söyleşi ve 1 masal yer almaktadır. Serbest okuma metinleri arasında ise 1 blog, 1 mektup, 2 hikâye, 2 deneme, 1 fabl ve 1 şiir türü bulunmaktadır.

\subsection{Türkçe Ders Kitaplarında Yer Alan Temalar}

2006 yılı Türkçe Dersi Öğretimi programında her sınıfta biri zorunlu Atatürk teması olmak üzere 6 ana tema ele alınır. 5. 6. sinıfta "Sevgi”, 7. sınıfta "Millî Kültür", 8. sinıfta "Toplum Hayatı" zorunlu ana temalardır. Zorunlu temalar diğer sınıflarda da işlenebilir. 2017 güncellenen program, 2018 yılında gözden geçirilerek tekrar yürürlüğe girmiştir. Yenilenen Türkçe Dersi Öğretimi Programında Türkçe Dersi Öğretim Programı'nın uygulanması sürecinde her sınıf düzeyinde 8 tema işlenmesi öngörülmüştür. Bu temalardan; "Erdemler", "Millî Kültürümüz", "Millî Mücadele ve Atatürk" temalarının her sınıf düzeyinde işlenmesi zorunludur. Zorunlu temalar dışında verilen diğer temalar seçmeli olup kitap yazarlarının tercihine bırakılmıştır.

Tablo 5. MEB Yayınevi Tarafından Hazırlanan 5. Sınıf Türkçe Ders Kitabında Yer Alan Temalar

\begin{tabular}{ll}
\hline 1. & Çocuk Dünyası \\
2. & Milli Mücadele ve Atatürk \\
3. Erdemler \\
4EMALAR
\end{tabular}

Tablo 5’te belirtilen bu temalardan; "Erdemler", "Millî Kültürümüz", "Millî Mücadele ve Atatürk" temalarının her sınıf düzeyinde isslenmesi zorunlu temalardandır. Yazarın tercihine bırakılan temalar ise "Çocuk Dünyası", "Bilim ve Teknoloji”, “Okuma Kültürü”, "Sağlık, Spor” ve "Doğa ve Evren" temalarıdir.

Tablo 6. MEB ve EKSEN Yayınevlerince Hazırlanan 6. Sınıf Türkçe Ders Kitaplarında Yer Verilen Temalar

\begin{tabular}{llll}
\hline & \multicolumn{1}{c}{ EKSEN } & \multicolumn{1}{c}{ MEB } \\
\cline { 2 - 3 } & 1. & Erdemler & 1. Okuma Kültürü \\
2. Millî Kültürümüz & 2. Millî Mücadele ve Atatürk \\
3. Millî Mücadele & 3. Bilim ve Teknoloji \\
4. Çocuk Dünyası & 4. Erdemler \\
5. Birey ve Toplum & 5. Doğa ve Evren \\
6. İletişim & 6. Millî Kültürümüz \\
7. Doğa ve Evren & 7. Sağlik ve Spor \\
8. Bilim ve Teknoloji & 8. Birey ve Toplum \\
\hline
\end{tabular}

Tablo 6 incelendiğinde hem Eksen hem de MEB yayınevlerince hazırlanan kitaplarda zorunlu temalar (Erdemler, Millî Kültürümüz, Millî Mücadele ve Atatürk) yer almaktadır. Ders kitapları arasında temalar açısından da farklılıklar bulunmaktadır. Eksen Yayınevi tarafından yayınlanan ders kitabında bulunan "Çocuk Dünyası" ve "İletişim" temaları MEB Yayınevi tarafindan 
yayınlanan ders kitabında yer almamaktadır. Bununla birlikte MEB Yayınevi tarafından hazırlanan ders kitabında "Sağlık ve Spor" ve "Okuma Kültürü" temaları yer alırken Eksen Yayınevi tarafından hazırlanan ders kitabında bu temalara yer verilmemiştir. Bu da farklı ders kitaplarıyla eğitim gören öğrencilerin farklı konu içerikli metinlerle karşı karşıya gelecekleri anlamina gelmektedir.

Tablo 7. MEB-A, DESDESTEK ve MEB-B Yayınevleri Tarafından Hazırlanan 7. Sınıf Türkçe Ders Kitaplarında Yer Alan Temalar

\begin{tabular}{lccc}
\hline TEMALAR & MEB- A & DERSDESTEK & MEB- B \\
\hline Erdemler & $\mathrm{X}$ & $\mathrm{X}$ & $\mathrm{X}$ \\
\hline Duygular & $\mathrm{X}$ & - & - \\
\hline Doğa ve Evren & - & $\mathrm{X}$ & $\mathrm{X}$ \\
\hline Millî Kültürümüz & $\mathrm{X}$ & $\mathrm{X}$ & $\mathrm{X}$ \\
\hline Millî Mücadele ve Atatürk & $\mathrm{X}$ & $\mathrm{X}$ & $\mathrm{X}$ \\
\hline Vatandaşlık & - & $\mathrm{X}$ & - \\
\hline Okuma Kültürü & $\mathrm{X}$ & - & $\mathrm{X}$ \\
\hline Sağlik ve Spor & - & $\mathrm{X}$ & - \\
\hline Kişisel Gelişim & $\mathrm{X}$ & - & $\mathrm{X}$ \\
\hline Sanat & $\mathrm{X}$ & $\mathrm{X}$ & - \\
\hline Zaman ve Mekân & - & - & $\mathrm{X}$ \\
\hline Bilim ve Teknoloji & - & $\mathrm{X}$ & $\mathrm{X}$ \\
\hline
\end{tabular}

Tablo 7 incelendiğinde de bütün ders kitaplarında zorunlu temalar (Erdemler, Millî Kültürümüz, Millî Mücadele ve Atatürk) yer almaktadır. Temaların ders kitaplarında yer alışında da farklılıklar bulunmaktadır. "Kişisel Gelişim” ve “Okuma Kültürü” MEB-A ve MEB-B'de yer alırken, Dersdestek Yayınevi'nde yer almamaktadır. Duygular (MEB-A), Sağlık ve Spor (DERSDESTEK), Vatandaşlık (DERSDESTEK) ve Zaman ve Mekân (MEB-B) temalarının her biri sadece bir ders kitabında bulunmaktadır. "Doğa ve Evren" temasına Dersdestek ve MEB-B yayınevlerince hazırlanan ders kitaplarında yer verilirken, MEB-A Yayınevi tarafından hazırlanan ders kitabında yer verilmemiştir. "Sanat" teması da MEB-A ve Dersdestek Yayınevi tarafından hazırlanan ders kitabında yer alırken, MEB-B tarafından hazırlanana kitapta yer almamaktadır. Tablodaki bulgulardan hareketle farklı ders kitaplarıyla eğitim gören öğrencilerin, farklı konu içerikli metin türleriyle karşı karşıya gelecekleri söylenebilir.

Tablo 8. MEB Yayınevince Hazırlanan 8. Sınıf Türkçe Ders Kitabında Yer Verilen Temalar
1. Kişisel Gelişim
2. Millî Mücadele ve Atatürk
3. Birey ve Toplum
4. Sanat
5. Millî Kültürümüz
6. Zaman ve Mekân
7. Erdemler
8. Hak ve Özgürlükler 
Tablo 8'de görüldüğü gibi ders kitabında zorunlu temaların yer aldığı görülmektedir. Yazarın tercihine bırakılan temaların da "Kişisel Gelişim", "Birey ve Toplum", Sanat", "Zaman ve Mekân" ve "Hak ve Özgürlükler" olduğu görülmektedir.

\section{SONUÇ}

Türkçe Dersi Öğretim Programı ile öğrencilerin hayat boyu kullanabilecekleri dinleme/izleme, konuşma, okuma ve yazma ile ilgili dil becerilerini ve zihinsel becerileri kazanmaları, bu becerileri kullanarak kendilerini bireysel ve sosyal yönden geliştirmeleri, etkili iletişim kurmaları, Türkçe sevgisiyle, istek duyarak okuma ve yazma alışkanlığ1 edinmeleri hedeflenmektedir (MEB, 2018). Programda varılmak istenilen amaçlara ulaşmada en önemli etken de öğrencilere okuma zevk ve alışkanlığının kazandırılmasıdır. Öğrencilerin bilişsel, duyuşsal ve devinişsel gelişimine katkı sağlamak, dil bilinci ve duyarlılığı oluşturarak okuma kültürü kazanmış bireyler olarak yetişmeleri Türkçe öğretiminin temel işlevidir (Sever, 2013a, s.15). Dilidüzgün'e (2018, s.7) göre de yazınsal değere sahip, estetik niteliği olan metinler, okuma anlama becerisini geliştirirken düşünme, karşılaştırma, eleştirme yeteneğimizi de artırmaktadır. Alanyazından elde edilen bulgulara göre ders kitaplarındaki metinlerin Türkçenin inceliklerini ve anlatım olanaklarını yansıtacak boyutta olmayışı, öğrencilerin gereksinimlerine, beğeni ve duyarlılıklarına seslenecek niteliklere sahip olmaması, dilin temel becerilerini kazandırmada etkili olamamalarının başlıca sebebidir (Canl1, 2015; Dilidüzgün, 2011, 2012; Hayran, 2011; Onan ve Tokdemir, 2012; Özbay ve Çeçen, 2012; 2013; Solak ve Yayl1, 2009).

Araştırmanın kapsamı bağlamında 2018-2019 yılında ortaokul 5., 6., 7. ve 8. sınıflar için ders kitabı olarak kabul edilen ve "MEB, EKSEN ve DERSDESTEK" yayınevlerince hazırlanan Türkçe ders kitapları, metin türleri ve temalar açısından incelenmiştir. Araştırma sonucunda ders kitaplarının tür bakımından zengin olduğu görülmüştür. Yenilenmiş Türkçe Öğretimi Programı'nda (2018) belirtilen metin tür sayısı önceki programlara göre fazladır. Blog, broşür, kılavuzlar, sosyal medya mesajları gibi türlere eski programlarda yer almamaktadır. Yenilenen program doğrultusunda hazırlanan ders kitaplarında da bu türlere yer verildiği görülmektedir. Ders kitaplarında dinleme / izleme metni olarak çizgi film, video, film ve belgesel gibi materyallere de yer verilmiştir. Dijital çağda yaşadığımız bu dönemde sesli ve görüntülü öğrenme seçeneklerinin ders kitabında yer alması ve öğrencilerin kullanımına sunulması önemlidir. İncelenen ders kitaplarında bazı türlerin çok az sayıda yer aldığı görülmektedir. Masal türü de bu türler arasında yer almaktadır. Gizemli havası ve serüven dolu fantastik olaylar içermesi yönüyle çocukların ilgisini çeken bu türün ders kitaplarında daha fazla yer alması gerekir. Benzer şekilde biyografi ve otobiyografi gibi türlerin de az olduğu görülmektedir. Güleryüz'ün (2013, s.428) de belirttiği gibi yurduna ulusuna, insanlığa yaptıklarıyla yararlı olan önemli kişilerin belirgin özelliklerini, üstün ve örnek alınabilecek yönlerini, başarılı olma yönlerini inceleyen metinlere ders kitaplarında daha fazla yer verilmelidir. Ders kitaplarında göze çarpan bir diğer husus ise tiyatro türünün yer alış sıklığıdır. Öğrencilerin kendilerini ifade etmesi, sosyalleşmesi gibi birçok açıdan faydalı bir metin türünün ders kitaplarında daha fazla yer alması önem arz etmektedir. Yalçın ve Aytaş'a (2011) göre tiyatro, insanın kişilik ve kimlik kazanmasında önemli sanat dallarından biridir. Bu açıdan bakıldığında metin sayısının artırılmasında fayda vardır.

Türkçe ders kitaplarına metin seçilirken tür çeşitliliği kadar türe ilişkin metin sayısı da önemlidir. Baş (2003), çalışmasında biri Millî Eğitim Bakanlığı biri de özel bir yayınevince hazırlanan 6. sınıf Türkçe ders kitaplarındaki metinleri incelemiş; kitaplardaki metinlerin türsel dağılımındaki dengesizliği belirtmiştir. Solak ve Yaylı (2009, ss.450-451) da 6-8 sinıf Türkçe ders kitaplarını türler açısından incelemişlerdir. Kitapların hazırlanmasında gerekli özenin gösterilmediğini, 
türlerin dengeli dağıtılmadığını, önemli türlere kitaplarda yer verilmediğini, öğrenci seviyesinin göz ardı edildiğini, gerçek hayatın kitaplara yansıtılmadığını, metinlerin çok uzun olduğunu ve metinler arası okumaya olanak tanımadığını ortaya koymuşlardır. Keklik (2009) ve Kolaç (2009) da yapmış oldukları çalışmalarında benzer sonuçlarla karşılaşmışlardır. Mevcut çalışmada da altıncı ve yedinci sınıf ders kitapları farklı yayınevlerince hazırlandığı için metin türü ve sıklıkları açısından farklılıklar bulunmaktadır. Tür dağılımlarının verildiği tablolardan da görüleceği gibi ders kitapları arasında tutarsızlıkların olduğu söylenebilir. Bu da öğrencilerin bazı metin türleriyle karşılaşmayacakları anlamına gelmektedir. Ders kitapları birden fazla yayınevi tarafından basılacak ise yer verilecek metin türlerinin benzer nitelikte ve sıklıkta olmasına dikkat edilmelidir.

Metinlerin temaları bakımından da ders kitaplarının zengin olduğunu söylemek mümkündür. "Okuma Kültürü” teması çocuğa okuma alışkanlığını kazandırılması açısından çok önemlidir. Bu nedenle bu temanın da zorunlu temalar içerisine dâhil edilmesi gerekmektedir. Yayınevlerince ileride hazırlanacak her kademedeki ders kitabında bu tema yer almalıdır.

Son olarak Türkçe ders kitabına metin seçiminde dikkatli olunmalıdır. Kitaplarda yer verilecek türlerde çocuk edebiyatı ürünlerinden daha fazla yararlanılmalıdır. Öğrencilerin okuma kültürü edinme sürecinde bir basamak niteliği taşıyan ders kitaplarına metin seçerken çocuk gerçekliği ve çocuk bakışını göz önünde bulunduran, sanatçı duyarlılığına sahip olan yazarların metinlerine daha çok yer verilmesi gerektiği anlaşılmaktadır. Kitap hazırlama aşamasında, özellikle metin seçiminde bu alanda uzman kişilerin görüşlerine ve desteğine başvurulmalıdır. Ders kitaplarında yer alan türler, çeşitlilik göstermeli ve türünün en güzel örneğinden seçilmelidir.

\section{KAYNAKÇA}

Arıcı, A. F. (2016). Çocuk edebiyatı ve kültürü. Ankara: Pegem.

Aktaş, Ş. (2015). Anlatma esasına bağlı edebî metinlerin tahlili (2. Baskı). Ankara: Kurgan

Edebiyat.

Akgül, A. ve diğerleri. (2018b). Ortaokul ve imam hatip ortaokulu Türkçe 7 ders kitabı. Ankara: MEB Yayınları.

Akyol, H. (2006). Yeni programa uygun Türkçe öğretim yöntemleri. Ankara: Kök.

Aytaş, G. (2006). Edebi türlerden yararlanma. Milli Eğitim, 168, s.261- 276.

Baki, Y. ve Karakuş, N. (2012). Türkçe öğretiminde öğretim teknolojileri ve materyal tasarımı. Ankara: Pegem.

Baş, B. (2003). Altıncı sınıf Türkçe ders kitaplarındaki metin türleri üzerine bir inceleme. Türklük Bilimi Araştırmaları, (13), 2003. Web site: http:/ /www.tubar.com.tr/TUBAR\%20DOSYA/pdf/2003BAHAR/20bayram\%20bas.257.p df adresinden 1 Eylül 2018 tarihinde erişilmiştir.

Beaugrande, R. ve Dressler, W.U. (1981). Introduction to text linguistics. London: Longman.

Canlı, S. (2015). Türkçe ders kitaplarına seçilecek metinlerin belirlenmesinde çocuğa görelik ilkesi. Dil Eğitimi ve Araştırmaları Dergisi, 1(1), 98-123.

Cemiloğlu, M. (2015). Türkçe öğretimi. Bursa: Alfa Aktüel.

Dilidüzgün, Ş. (2011). İlköğretim Türkçe metin çalışmalarında metin türü farkındalığı. G. L. Uzun ve Ü. Bozkurt (Eds.) içinde, Theoretical and Applied Researches on Turkish Language 
Teaching/Türkçenin Eğitimi Öğretiminde Kuramsal ve Uygulamalı Araştırmalar (ss. 459474). Essen: Die Blaue Eule.

Dilidüzgün, S. (2012). Edebiyat öğretimi ve okur yetiştirme sorunu. 5. Uluslararası Türkçenin Eğitimi-Öğretimi Kurultayı Bildirileri 05-06 Temmuz 2012 içinde (ss.1-9). Mersin: Mersin Üniversitesi ve TÜBİTAK Yayını.

Dilidüzgün, S. (2018). Çăgdaş çocuk yazını. İzmir: Tudem.

Erden, M. (1995). Eğitimde program değerlendirme (2. Basım). Ankara: Pegem.

Göçer, A. (2017). Türkçe özel öğretim yöntemleri. Ankara: Pegem.

Güleryüz, H. (2013). Yaratıcı çocuk edebiyatı. Ankara: Edge Akademi.

Günay, V. D. (2013). Metin bilgisi. İstanbul: Papatya.

Güneş, F. (2013) Türkçe öğretiminde metin seçimi. Ana Dili Eğitimi Dergisi, 1 (1), 1-12.

Güneş, F. (2014). Türkçe öğretimi yaklaşımlar ve modeller. Ankara: Pegem Akademi.

Hartman, D. K., ve Allison, J. (1996). Promoting 1nquiry oriented discussions using multiple texts (pp. 106-133). In L. B. Gambrell \& J. F. Almasi's (Eds.) Lively Discussions: Fostering Engaged Reading. Newark DE: International Reading Association.

Haykır, H.A ve diğerleri. (2018). Ortaokul ve imam hatip ortaokulu Türkçe 5 ders kitabı. Ankara: MEB Yayınları.

Hayran, Z. (2011). İlköğretim 5. sınıf Türkçe derslerinde metin türlerinin okuma becerisine etkisi. III. Uluslararası Türkçenin Eğitimi-Öğretimi Kurultayı Bildirileri içinde (ss.199-210). Dokuz Eylül Üniversitesi DEDAM, İzmir: Dokuz Eylül Üniversitesi Yayınları.

İşeri, K. (2014). Türkçe ders kitaplarındaki metinlerin metinsellik özellikleri. H. Ülper (Ed.), Türkçe ders kitabı çözümlemeleri (ss. 91-112). Ankara: Pegem.

Kaya, B. (2018). Ortaokul ve imam hatip ortaokulu Türkçe 7 ders kitabı. Ankara: Dersdestek Yayınları.

Kantemir, E. (1995). Yazılı ve sözlü anlatım. Ankara: Engin.

Keklik, S. (2009). 1-8. sınıf Türkçe dersi ders kitaplarının metin türleri ve özellikleri açısından incelenmesi. I. Uluslararası Türkiye Eğitim araştırmaları Kongresi www.oc.eab.org.tr/egtconf/pdfkitap

Kır, T. ve diğerleri. (2018a). Ortaokul ve imam hatip ortaokulu Türkçe 7 ders kitabı. Ankara: MEB Yayınlar1.

Kıran, A. ve Kıran, Z. (2011). Yazınsal okuma süreçleri. Ankara: Seçkin.

Kolaç, E. (2009). İlköğretim Türkçe ders kitaplarında yer alan metinlerin tür açısından değerlendirilmesi. Uluslararası İnsan Bilimleri Dergisi. Erişim: http:/ / www.insanbilimleri.com

MEB (2006). İköğretim Türkçe dersi (6, 7, 8. Sinıflar) öğretim programı. Ankara: Millî Eğitim Bakanlı̆̆ı.

MEB (2015). Türkçe dersi (1-8. Sinıflar) öğretim programı. Ankara: Millî Eğitim Bakanlığı.

MEB (2017). Türkçe dersi (1-8. Sinıflar) öğretim programı. Ankara: Millî Eğitim Bakanlığı. 
MEB (2018). Türkçe dersi (1-8. Sinıflar) öğretim programı. Ankara: Millî Eğitim Bakanlığ1.

Mete, G. ve diğerleri. (2018). Ortaokul ve imam hatip ortaokulu Türkçe 8 Ders Kitabı. Ankara: MEB Yayınları.

Okur, A. (2014). Türkçe ders kitaplarındaki metinlerin türsel özellikleri. H. Ülper (Ed.), Türkçe ders kitabı çözümlemeleri (s. 115-140). Ankara: Pegem.

Onan, B. ve Tokdemir, N. (2012). İlköğretim ikinci kademe Türkçe ders kitaplarında uzak bağdaştırma kullanımı üzerine bir araştırma. Mustafa Kemal Üniversitesi Sosyal Bilimler Enstitüsü Dergisi, 9(18), 29-44.

Onursal, İ. (2003). “Türkçe metinlerde bağdaşıklık ve tutarlılık”. Günümüz Dilbilim Çalışmaları (s. 121-132). İstanbul: Multilingual Yayınlar1.

Özbay, M. ve Çeçen, M. A. (2012). Türkçe ders kitaplarında (6-8. Sinıflar) yer alan metinlerin tür ve tema açısından incelenmesi. Dil ve Edebiyat Eğitimi Dergisi, 1(1), 67-76.

Özcan, A. F. (2017). İlköğretim Türkçe dersi öğretim programlarının tarihî gelişimi, A. Güzel (Ed.), Başlangıçtan Günümüze Türkçenin Eğitim- Öğretim Tarihi (s. 520- 562). Ankara: Akçağ.

Sever, S. (2013a). Etkinliklerle Türkçe öğretimi. Ankara: Tudem.

Sever, S. (2013b). Çocuk ve edebiyat. Ankara: Tudem.

Sever, S. (2013c). Çocuk edebiyatı ve okuma kültürü. Ankara: Tudem.

Solak, M. ve Yaylı, D. (2009). İlköğretim ikinci kademe Türkçe ders kitaplarının türler açısından incelenmesi. Uluslararası Sosyal Araştırmalar Dergisi, 2, 444-453.

Şekerci, Y. (2018). Ortaokul Türkçe 6 ders kitabı. İstanbul: Eksen Yayıncılık.

Tansel, F. A. (1987). İyi ve doğru yazma usulleri III. İstanbul: Kubbealt1.

Uçgun, D. (2014). Tarihî süreç içerisinde Türkçe öğretim programları ve Türkçe öğretmenlerinin yetiştirilmesi. A. Güzel ve H. Karatay(Ed.), Türkçe Öğretimi (s. 89- 106). Ankara: Pegem.

Yıldırım, A. ve Şimşek, H. (2013). Sosyal bilimlerde nitel araştırma yöntemleri. Ankara: Seçkin.

Y1lmaz, E. (2010). Uygulamalı metin bilgisi. Ankara: Pegem.

Yalçın, A. ve Aytaş, G. (2005). Çocuk edebiyatı. Ankara: Akçağ Yayınları. 